\title{
The Results Presentation of The Test Plants As A Natural Indicator of The Test Compounds of The Acid-Base Balance In the Teaching Materials of The Atlas to Train Scientific Reasoning Students
}

\author{
Raddina Aprilia Putri ${ }^{1}$, Endang Susantini ${ }^{2}$, Titik Taufikurohmah ${ }^{3}$ \\ 1,2,3 Universitas Negeri Surabaya, Surabaya, Indonesia
}

\begin{tabular}{|c|c|}
\hline (A) Check for updates open ${ }^{\text {access }}$ CC) & DOI : https://doi.org/10.46245/ijorer.v2i3.116 \\
\hline SectionsInfo & ABSTRACT \\
\hline Article history: & The type of research applied in this research is Research and Development. \\
\hline Submitted: April 26, 2021 & The development model used is Dick and Carrey. The purpose of this \\
\hline Final Revised: May 17, 2021 & research and development is to design an Atlas and apply it to train the \\
\hline Accepted: May 18, 2021 & students' scientific reasoning abilities. Atlas is a teaching materials \\
\hline Published Online: May 31, 2021 & developed and applied to high school / vocational / MA level students. \\
\hline Keywords: & The sample chosen for the implementation of the Atlas of teaching \\
\hline Atlas of acid-base & materials was grade $X$ of VOCATIONAL Health Yannas Husada \\
\hline Natural indicator & Bangkalan students. The application of plants as natural indicators of acid- \\
\hline Scientific Reasoning & base tests is the material presented in the developed Atlas. Plants selected \\
\hline Teaching materials & $\begin{array}{l}\text { as indicators are tested first to be presented in the Atlas. Atlas is a teaching } \\
\text { material that can convey information related to the use of natural }\end{array}$ \\
\hline 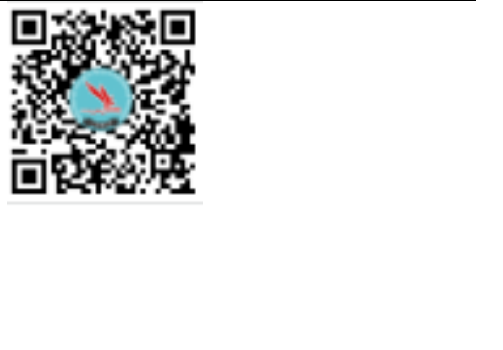 & $\begin{array}{l}\text { indicators of the acid-base test to train the students' scientific reasoning } \\
\text { skills. The four indicators of scientific reasoning that are trained are } \\
\text { Theoretical Reasoning, Proportional Reasoning, Probabilistic Reasoning, } \\
\text { and Correlational Reasoning. The data shows the students' scientific } \\
\text { reasoning ability on the post-test results, as many as } 20 \% \text { of students are on } \\
\text { the high criteria, } 60 \% \text { are moderate criteria, and } 20 \% \text { are still on the low } \\
\text { criteria from the post-test results. The post-test result data is quite } \\
\text { increased when compared to the pretet results, which } 100 \% \text { of students are } \\
\text { in the low criteria. }\end{array}$ \\
\hline
\end{tabular}

\section{INTRODUCTION}

Acids and bases are one of the studies in the science of chemistry that studies the properties of a substance or material. Compounds that are acids and bases can be detected physically and chemically. The method is chemically more appropriate to be used in the process of testing compounds that are acids and bases. Methods the chemical can test the content of the compound of the acid-alkaline balance in all substances or ingredients, both of which are toxic and non-toxic. Phenolphthalein, Methyl Orange, Brom Thymol Blue, Paper, Universal Indicator and Litmus Paper is an indicator of synthetics used to test the compounds of the acid-base chemical (Jain et al., 2013). Some of the chemical compounds that are used as an indicator of the synthetic because at each $\mathrm{pH}$ range can produce different color changes (Vadivel \& Chipkar, 2016).

Indicators synthetic widely used can cause pollution of the environment, if the waste is not given special treatment (Mahmud et al., 2018). The use of a natural indicator for test compounds acid-base balance can be a solution to replace the indicator is synthetic, so it can cope with the influx of pollutants to the environment (Senathirajah et al., 2017). Some of the plants that have the pigment of bright and dark colors can be used as a 
natural indicator to test the compound of the acid-alkaline balance. A group of flavonoid compounds contained in plants have the same characteristics as the indicator of the synthetic. Anthocyanin and Curcumin is an example of a chemical compound belonging to the group of flavonoid compounds that are quite susceptible to changes in pH of the (Trojak \& Skowron, 2017).

Anthocyanin and curcumin contained in plants can be found in the parts of the flower, the fruit and the skin of the fruit, leaves or crop, even the root or rhizome. Anthocyanin can give the colors of orange, red, purple, and blue in some parts of the plant (Khoo et al., 2017). Curcumin can produce the color yellow pigment in plants (Lee et al., 2013). Herbs that has a color of orange to dark red on some parts of his body, like a flower Flamboyant, Fruit Murbay, Flower Four o'clock, Flower Shoes, Dragon Fruit Skin, and spinach leaves red can be tested for its effectiveness as an indicator of natural (Al-Snafi, 2018; Ariami et al., 2018; Laurencia \& Tjandra, 2018; Shanmukha et al., 2011; Shishir et al., 2014). Plants that have high levels of Blue to purple in some parts, can also be detected its effectiveness as a natural indicator, such as purple Cabbage, Flowers Starfruit, and Flowers ruelia(Moresco et al., 2012; Song et al., 2018; Tejaputri et al., 2019). Turmeric as one of the herbs that contain curcumin, also need to be tested to measure its effectiveness as a natural indicator for the test compounds of the acid-base (Kumavat et al., 2013).

Some herbs that could potentially have elevated levels of anthocyanin and curcumin high, will be reaksikan with some chemical compound that has a $\mathrm{pH}$ range of acidic, neutral, and alkaline. The success of this study can provide new information on the world of education is to minimize the use of indicators syntheticimprove the use of a natural indicator for the test compounds of the acid-base(Senathirajah et al., 2017). In addition, the results of this study can be presented in teaching materials in the form of Atlas. The use of plant natural indicators presented in the Atlas can help the chemistry teacher to present the material as train scientific reasoning of students.

Atlas is a teaching material which serves a variety of images, accompanied by a complete description and detailed (Wulansari, 2015). Atlas as the material of interactive teaching that can be used as a supplement supporting the activities of the practicum, the media confirmation to train the skills of reasoning students(Kusuma et al., 2018). The skills of reasoning to students, such as the skills of reasoning scientific is the most important part that needs to be mastered by the students to make it easier to apply the theories of science in solving the problem. Practicum is the most important part in the process of learning chemistry, especially in proving the various theories, such as the theory of acid-base (Harefa \& Dewi Silalahi, 2020). Skills reasoned scientific can be applied to resolve the issue through analysis and pengamplikasikan theory and the evaluation of the relationship between the two variables as well as the possibility of the accuracy of the solution that will be applied (Kambeyo, 2017).

The skills of scientific reasoning can be trained with reference to the indicators of the theoretical reasoning, proportional reasoning, probabilistic reasoning, and correlational reasoning (Khoirina et al., 2018).The development and implementation of the Atlas that presents information related to the use of herbs as a natural indicator is a solution that can be used to train the scientific reasoning of students. In line with this, this research will lift the title "the Presentation of the Results of the Test Plants As a Natural Indicator 
of the Test Compounds of the Acid-Base balance In the Teaching Materials of the Atlas To Train Panalaran Scientific Students."

\section{RESEARCH METHOD}

The research method actually refers to the method of research and development. The main purpose of this study is to train the scientific reasoning of students through the use of herbs as a natural indicator test acid-base presented in the Atlas. The population that is in use in the process of training of scientific reasoning is the students at the level of Senior High School di Kabupaten Bangkalan. The sample chosen is a VOCATIONAL student Health yannas Husada Bangkalan. The first stage of the research procedure perform the test qualitative test your retention of the content of anthocyanin and curcumin from several organs of the plant as an indicator of natural compounds acidalkaline balance. The organs of the plants selected as a natural indicator is on the leaves, flowers, fruit and the skin of the fruit.

\section{Natural Indicator Creation Procedure}

- Sample preparation. Parts of the plant that will be used in the rinse first using water to remove the dirt.

- The making of an extract. 30 grams of plant in the puree with the use of $50 \mathrm{~mL}$ of water. Plants that have been blended will be filtered to get the extract which is rich in anthocyanin content. The plant extract is put in the beaker that has been given the code.

- The identification of color changes in each solution of the Acid-Base balance. Five test solution as much as $35 \mathrm{~mL}$ placed in a test tube and measure the ph using universal indicator paper. As many as 10 drops of plant extract in the mix with each test solution and observe the color change that is produced.

- The analysis of compounds that are acidic, base, and neutral based on the results of testing. To remove a solution of the test results on the test tube into the sized bottles of 35 $\mathrm{mL}$. Analyzing compounds that are acidic, alkaline, and neutral based on the color that is produced in each solution.

The second stage of the procedure of this research is to develop the Atlas presents information about the effectiveness of the few plants that contains anthocyanin and curcumin as a natural indicator of the test compounds acid-alkaline balance. The third stage of the procedure of this research is to test the validity and reliability of the instrument.

This analysis technique is aimed at measuring the feasibility of learning devices, especially the products being developed. The following is the formula used to measure the validity or feasibility of the product being developed.

$R=\frac{s}{N} \times 100 \%$

Meanwhile, the following formula is used to test reliability in order to determine the extent to which the product can be trusted. The reliability test used in this research and development is the Borich formula (Percentage Agreement).

$$
\mathrm{PA}=\left(1-\frac{A-B}{A+B}\right) \times 100 \%
$$


The fourth stage of the procedure of this research is to test the effectiveness of the Atlas to train the ability of scientific reasoning of students. There are four main indicators to train the scientific reasoning of students, namely theoretical reasoning, proportional reasoning, probabilisric reasoning, and correlational reasoning. The criteria of the ability of scientific reasoning of students based on the interpretation in Table 2.

Table2. The criteria of the Ability of Scientific reasoning.

\begin{tabular}{cc}
\hline Score & Criteria \\
\hline $\mathrm{N} \geq 71,61$ & High \\
$61,73<\mathrm{N}<71,61$ & Are \\
$\mathrm{N} \leq 61,73$ & Low \\
\hline
\end{tabular}

\section{RESULTS AND DISCUSSION}

The Effectiveness of The Content of Anthocyanin and Curcumin From Some Herbs As A Natural Indicator Test Acid-Base Balance

Each plant extract that is used as the research sample have a variety of colors. The difference in color of the resulting extract refers to the levels of the pigment anthocyanin and the curcumin contained in it. Table 3 Presents the color of the extract of each plant used as a research sample. Based on the data presented in Table 3 of the color red and the color of purple is the average color of the extract that is produced by plants containing anthocyanin. Red and purple color can be caused by efektvitas of anthocyanin, which is easily soluble in water (Nurtiana, 2019).

Extracts from plants containing curcumin, produce color that is quite different with extracts of plants that contain anthocyanin. Based on Table 3 extract containing curcumin produces a yellow color. Curcumin is a compound that is not stable in water (Kumavat et al., 2013). So the color of the extract that is produced will be the same color as the base of the plant contains curcumin that.

Table 3. Color extract which is generated by the sample of plants as a natural indicator.

\begin{tabular}{ll}
\hline \multicolumn{1}{c}{ Sample } & \multicolumn{1}{c}{ Initial Color of the Extract of the } \\
\hline Flowers of the Flamboyant(Delonixregia) & Orange Brownish \\
Leaves of Red Spinach (Amaranthus tricolor) & dusky Red \\
Flowers At Four o'clock (Mirabilis jalapa L) & Pink Purplish \\
Fruits of Mulberry (Morus alba) & Dusky Red \\
Turmeric (Curcuma longa L) & Yellow \\
hibiscus (Hibiscus rosa sinensis) & Red \\
Flower Ruelia(Reuliaimplex) & Blackish Purple \\
Flowers Bougenvil(Bougainvillea spectabiliswilld) & The purple \\
Skin of the Dragon Fruit (Hylocereusundatus) & Red \\
Purple Cabbage (Brassica oleraceavar.capitata L) & Purple Blackish \\
\hline
\end{tabular}

The color pigments in the plant that is used as the sample of the study consists of two types, namely anthocyanins and curcumin. The effectiveness of the color change that is produced anthocyanin and curcumin on any range of $\mathrm{pH}$ is presented in Table 4 Anthocyanins are compounds that have the characteristics of the carbon skeleton with the structure of the 2-phenyl-benzofirilium, as in figure 3.1 (Priska et al., 2018). Anthocyanin can have a variety of different colors based on the number of protons that are released as well as the number of protons, which still binds to the molecule (Khoo et al., 2017). Based on Table 4 of anthocyanin produce a red color in acidic conditions, it 
produces purple and blue color in conditions of neutral $\mathrm{pH}$ and at alkaline conditions will produce a green color and yellow color.

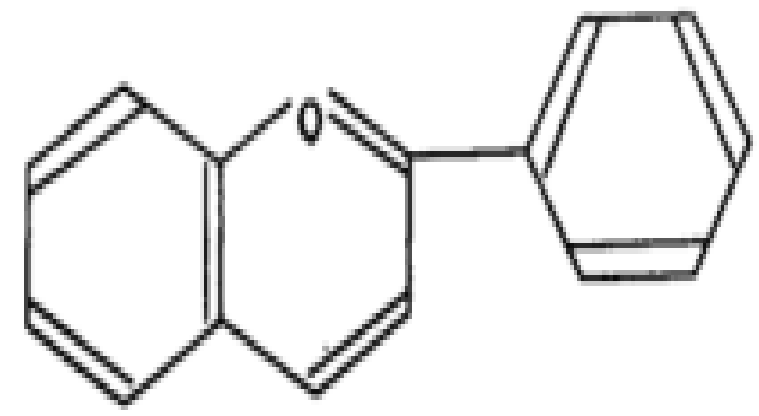

Figure 1. The structure of the compound anthocyanin (Source: Khoo et al (2017).

Change the color of anthocyanins may be affected by molecular changes of anthocyanin due to be in the range of $\mathrm{pH}$ diverse. Suzihaque et al (2019) explain the molecular changes of anthocyanin in each $\mathrm{pH}$ range. 1) In acidic conditions, namely $\mathrm{pH}$ $1-3$, cation flavylium dominant will emit light that is colored red. 2) At a $\mathrm{pH}$ of $4-5$, carbinols alkaline facades are the dominant form caused by the hydration of the molecules that look colorless. 3) At $\mathrm{pH}$ 6-7, anthocyanin compound will form the structure of the quinoidal purple. 4) Furthermore, at $\mathrm{pH} 8-10$, the structure of the anionic will be formed and emit a blue color. 5) In the $\mathrm{pH}$ range of 11 to 14 ring the center on the compound anthocyanin will open and form a chalcone that emits a yellow color.

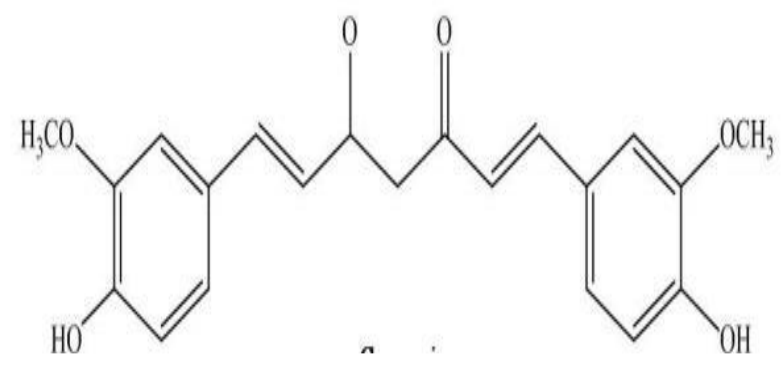

Figure 2. The chemical structure of curcumin (Source: Lee, 2013).

Curcumin is a chemical compound that is readily soluble in alkali and is not stable in acidic conditions and water (Kumavat et al., 2013). Curcumin has a chemical structure as in figure 2 with the IUPAC name 1,7-bis (4-hydroxy-3 - methoxy phenyl) -1,6 -heptadiene - 3,5-dione(Hong \& Lee, 2016). Based on Table 4 change the color that is produced by curcumin in acidic and neutral will produce a yellow color and in alkaline conditions will produce the colors red brick and red brick brown. Curcumin can experience changes in the structure of the molecules in each $\mathrm{pH}$ range. In the conditions of acidic and neutral conditions, i.e. in the $\mathrm{pH}$ range $2-7$, the main constituent of which is formed from the molecules of bis-keto. Curcumin which is formed in the molecule bisketobertindah as a donor of protons. In alkaline conditions, namely the range of $\mathrm{pH}>8$, the shape of the enolat of the chain heptadienonwill dominate, so that allows the curcumin to act as an electron donor and produces a brick-red color (Lee et al., 2013).

Variety of color produced by anthocyanins, as tersaji in Table 4 are quite diverse in each $\mathrm{pH}$ range. However, in plants that contain compounds curcumin only produce the 
color changes in the condition of $\mathrm{pH}$ above a $\mathrm{pH}$ of 7 . Test solution used is necessary to measure $\mathrm{pH}$ using universal indicator paper, before reaksikan with plant extracts. Universal indicator paper is very important used to determine the condition of the $\mathrm{pH}$ of the solution to be tested. So, change the color that is produced when reacted with plant extracts can be correlated with $\mathrm{pH}$ range.

Table 4. Effectiveness of plant pigments on the color change on the test results in each ph range.

\begin{tabular}{ccc}
\hline & \multicolumn{2}{c}{ Change Colors of the Test Results } \\
\cline { 2 - 3 } & Anthocyanin & Curcumin \\
\hline 1 & dark Red, Pink, And Pink Purple & Yellow \\
4 & Pink And Purple & Yellow \\
7 & Orange, Brown, Purple, Blue, Green And & Yellow \\
9 & light Green, And Yellowish Green to & Brownish Red \\
13 & dark Yellow And light Yellow & Red Brick \\
\hline
\end{tabular}

Plants contain anthocyanin produces color changes that are significant when it is reacted with a solution in the acid, neutral, and alkaline conditions. Based on the results of the experiment, plants contain anthocyanin produces the red color on the condition of strong acid, the color pink on the condition of the weak acid and the green color on the condition of the weak base as well as produce a yellow color on the condition of strong bases. However, in the neutral condition showed a variety of different colors. the resulting color on the neutral condition showed the initial color of the extract of each plant (Khoo et al., 2017).

\section{The Development of The Atlas of Plants Test Indicator Acid-Base Balance}

Atlas of Plants Test Indicator Acid-Base balance of the developed load a variety of material components of interactive teaching. The Atlas contains some may be important, such as Title explains the material in it, the Foreword and the Charge of the List of Contents of the Atlas, Symbols or instructions of the charge components of scientific reasoning, the Material along with supporting images as well as a Glossary. Atlas as a teaching material able to present the material with clear, detailed, and supported by the presentation of images (Setiawati et al., 2019). Atlas of Plants Test Indicator Acid-Base contains a fairly detailed description of the results of the identification and testing of multiple natural materials as an indicator of the compound of the acid-alkaline balance. Atlas present the scientific name and the morphology with images intact plant indicators. Furthermore, the Atlas contains the phytochemical content and the image portion of plants that is effective as a natural indicator. Penyajikan the last topic that the test results of the acid-alkaline balance.

The quality of the atlas plant test indicator acid-base when viewed from the results of the assessment of the validator, indicates that the topic in the atlas load the training of scientific reasoning. The level of validity and reliability of the Atlas of Plants Test Indicator Acid-Base which shows that the Atlas criteria are very valid with a score of $90.18 \%$ and also reliable with a score of $97.62 \%$..Atlas is a teaching material which is 
very useful for culture and the process of reasoning to evaluate the diverse scientific phenomena (Hong \& Lee, 2016). The process of applying the Atlas of plants test indicator acid-base balance in the activity of learning is in accordance with the type of learning received (ekspository) that are meaningful from David Ausubel.

The Effectiveness of The Use of Atlas to Train The Ability of Scientific Reasoning Students The development of the times, which is directly proportional to the height of the global challenges, the world is demanding education is to prepare the young generation that is able to solve diverse problems in a timely manner as well as based on the theory valid. Scientific reasoning is a form of cognitive skills is important enough to be mastered by the students. Scientific reasoning can dilatikan with conditioned students to perform the process of the analysis of the causal occurrence of diverse phenomena scientifically, evaluate valid whether or not a concept, opinion or solution, especially in solving problems (Wuriyudani et al., 2018).

Atlas of plants test indicator acid-base balance is the teaching material that is quite effective for guiding and culture and the ability of scientific reasoning of students. The process of scaffolding is a solution that is important to assist students in activating students in constructing a theory that can be used as a preparation in the process of reasoning (Wu et al., 2016). Atlas of plants test indicator acid-base balance presents the features which contain the four indicators of scientific reasoning. In line with this, the atlas test indicator acid-base balance can lead students to analyze, evaluate and find a valid troubleshooting.

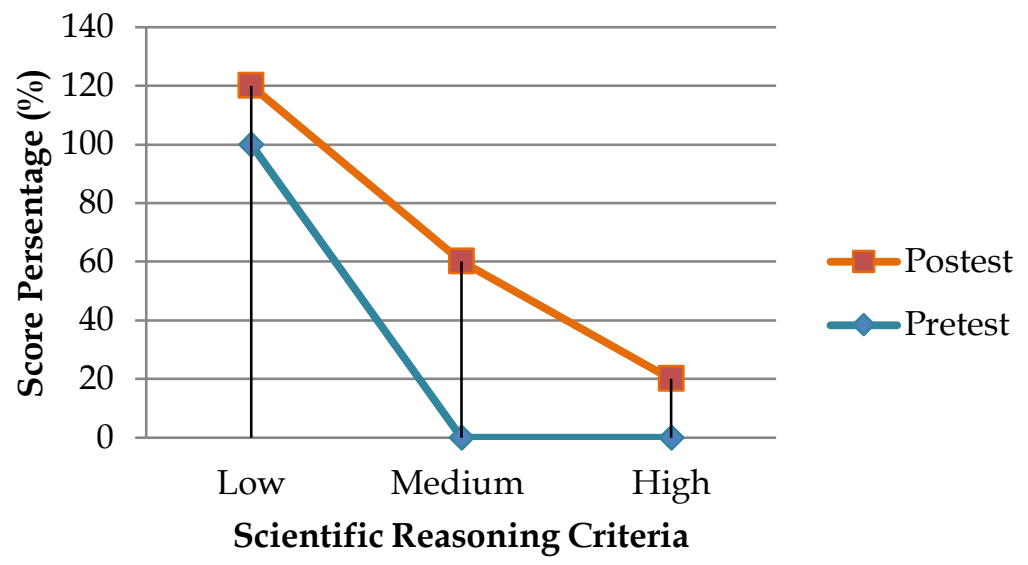

Figure 3. Recapitulation of the average score scientific reasoning students.

The ability of scientific reasoning is the cognitive aspects that can bring students to make important contributions in scientific problem at the global level. In line with this, the selection of scaffolding that right needs to be realized(Koenig et al., 2012). Based on figure 3 shows that the use of the atlas plant test indicator acid-base balance can provide a positive contribution to the training of scientific reasoning. The ability of scientific reasoning has increased signitifikan based on the results of the pretest and the results postetst. The Data shown in figure 3 students almost in its entirety has not been able to analyze scientifically. However, after the implementation of the atlas plant test indicator acid-base balance, left only $20 \%$ of students that are still at kateogori low. In 
line with this shows that as many as $60 \%$ of students and $20 \%$ of the students based on the results of postets 've been able to do reasoning scientifically.

In general, almost $80 \%$ of students are able to apply the theory and analyze the cause and effect of a phenomenon and evaluate the accuracy of the proportions and the level of validity of a statement is scientific which can then be used to solve problems (Rimadani et al., 2017). The reason behind the increasing ability of scientific reasoning students, certainly can not be separated from the quality of the presentation of the material in the atlas. Basically, students will easily do scientific reasoning if facilitated with the presentation of information that is able to bring the students to the process of analysis and evaluation (Novia \& Riandi, 2017).

The ability of scientific reasoning in $20 \%$ of the students who are still in the low category, of course, a result of several factors, both internal and external. Basically, students have not been able to master the theory as well as experience difficulties in applying them (Sari et al., 2019). Students also have the characteristic of solving problems that don't seem to notice some of the variables that factor into the cause of the (Nurhayati et al., 2016). Basically, there are still some students who have a weakness for doing literacy teaching materials in the form of books such as atlas.

Atlas as material teaching have a correlation which is very positive with the results of the training of scientific reasoning of students(Kusuma et al., 2018). Atlas of plants test indicator acid-base guide students in understanding the theory of acid-base balance as well as the application and analysis of the application of the theory. In line with this, students are trained to perform theoretical reasoning. Atlas of plants test indicator acidbase balance also brings students determine the ratio of the right materials to do the test compounds of the acid-base using plant extracts. The use of the Atlas plant test indicator acid-base, serving a variety of problems related to the comparisonperbnadingan material well testing sample test and indicator testing. The procedure of training refers to the training of proportional reasoning because notice the use of the proportion of appropriate materials. Atlas of plants test indicator acid-base balance can also contribute to the students in analyzing the reasons behind the success of the use of herbs as a natural indicator. As well as helping students to evaluate the accuracy of the opinions related to the use of a natural indicator to test the acid-base balance and the color change resulting from each extract when reacted with the test solution. In line with this, refer to the training correlational reasoning and probabilistic reasoning.

\section{CONCLUSIONS}

Plants that have natural color pigments that are very strong and very effective to be used as natural indicators of acid-base tests. The plants selected as natural indicators only consist of ten types of plants that are easily found in the surrounding environment. The research sample is limited to vocational students only. Based on the results, students managed to get postets which were quite good when compared to the pretest scores before implementing the atlas. The data shows as many as $20 \%$ of students are on high criteria, $60 \%$ are medium criteria, and $20 \%$ are still on low criteria from the postest results. The post-test result data is quite increased when compared to the pretet results where $100 \%$ of students are in the low criteria. Information related to the use of plant atlas as a natural indicator of acid-base compounds is very appropriate as a solution to support innovative learning for actors in the world of education. Following up on the 
use of plants as natural indicators, it is necessary to conduct trials on several parts of plant organs that contain dyes other than anthocyanins and curcumin.

\section{ACKNOWLEDGEMENTS}

Thanks, We convey to the Principal, Board of Teachers, Administrative Staff and Laboratory Assistants as well as students at the Yannas Husada Bangkalan Vocational High School for supporting the completion of the research process.

\section{REFERENCES}

Al-Snafi, A. E. (2018). Chemical constituents, pharmacological effects and therapeutic importance of Hibiscus rosa-sinensis-A review. International Journal of Pharmaceutical Research, 10(3), 451-475.

Ariami, P., Farida, \& Jubair. (2018). Potensi Teh daun bayam merah (amaranthus tricolor 1) terhadap aktivitas penghambatan tahap pembelahan sel (anti mitosis) sel embrio bulu babi (diedema antillarum). Jurnal Analis Mediaka Bio-Sains, 5(2), 114-124. https:// doi.org/10.32807/jambs.v5i2.115

Harefa, N., \& Dewi Silalahi, N. F. (2020). Improvement of student's learning outcomes and motivation with chemical practicum e-module. Jurnal Pendidikan Kimia, 12(1), 10-19. https:// doi.org/10.24114/jpkim.v12i1.17708

Hong, J. E., \& Lee, H. K. (2016). The use of middle school atlases in the social studies classroom in South Korea. International Journal of Geospatial and Environmental Research, 3(1), 2-15.

Jain, P. K., Jain, P., \& Jain, P. (2013). Green chemistry: Petal sap of Delonix regia as a substitute for hazardous internal indicators in volumetric analysis. Biosciences Biotechnology Research Communications, 6(2), 186-189.

Kambeyo, L. (2017). Scientific reasoning skills: A theoretical background on science. NERA Journal, 14(January 2017), 40-64.

Khoirina, M., Cari, C., \& Sukarmin. (2018). Identify students' scientific reasoning ability at senior high school. Journal of Physics: Conference Series, 1097(1). https://doi.org/10.1088/1742-6596/1097/1/012024

Khoo, H. E., Azlan, A., Tang, S. T., \& Lim, S. M. (2017). Anthocyanidins and anthocyanins: Colored pigments as food, pharmaceutical ingredients, and the potential health benefits. Food and Nutrition Research, 61(1). https://doi.org/10.1080/16546628.2017.1361779

Koenig, K., Schen, M., \& Bao, L. (2012). Explicitly targeting pre-service teacher scientific reasoning abilities and understanding of nature of science through an introductory science course abstract. Winter, 21(2), 1-9.

Kumavat, S. D., Chaundhari, Y. S., Borole, P., Mishra, P., Shenghani, K., \& Duvvuri, P. (2013). Degradation studies of curcumin. International Journal of Pharmacy Review and Research, 3(1), 6-11.

Kusuma, R. D., Rohman, F., \& Syamsuri, I. (2018). Pengembangan Atlas keanekaragaman hayati berbasis potensi lokal untuk SMK jurusan pertanian. Jurnal Pendidikan, 3, 296-301.

Laurencia, E., \& Tjandra, O. (2018). Identifikasi senyawa kimia ekstrak metanol buah naga merah ( hylocereus polyrhiz ) dengan kromatografi gas. Tarumanagara Medical Journal, 1(1), 67-73. 
Lee, W.-H., Loo, C.-Y., Bebawy, M., Luk, F., Mason, R., \& Rohanizadeh, R. (2013). Curcumin and its derivatives: Their application in neuropharmacology and neuroscience in the 21st Century. Current Neuropharmacology, 11(4), 338-378. https://doi.org/10.2174/1570159x11311040002

Mahmud, N. R. A., Ihwan, \& Jannah, N. (2018). Inventarisasi Tanaman berpotensi sebagai indikator asam-basa alami di kota Kupang inventory of plants potentially as natural indicator of acid-base in the city of Kupang. Prosiding Seminar Nasional Biologi Dan Pembelajarannya Inovasi Pembelajaran Dan Penelitian Biologi Berbasis Potensi Alam, 2008, 491-496.

Moresco, H. H., Queiroz, G. S., Pizzolatti, M. G., \& Brighente, I. M. C. (2012). Chemical constituents and evaluation of the toxic and antioxidant activities of Averrhoa carambola leaves. Brazilian Journal of Pharmacognosy, 22(2), 319-324. https:// doi.org/10.1590/S0102-695X2011005000217

Novia, N., \& Riandi, R. (2017). The analysis of students scientific reasoning ability in solving the modified lawson classroom test of scientific reasoning (MLCTSR) problems by applying the levels of inquiry. Jurnal Pendidikan IPA Indonesia, 6(1), 116-122. https://doi.org/10.15294/jpii.v6i1.9600

Nurhayati, N., Yuliati, L., \& Mufti, N. (2016). Pola Penalaran ilmiah dan kemampuan penyelesaian masalah sintesis fisika. Jurnal Pendidikan: Teori, Penelitian, Dan Pengembangan, 1(8), 1594-1597.

Nurtiana, W. (2019). Anthocyanin As Natural Colorant: a Review. Food ScienTech Journal, 1(1), 1. https://doi.org/10.33512/fsj.v1i1.6180

Priska, M., Peni, N., Carvallo, L., \& Ngapa, Y. D. (2018). Antosianin dan Pemanfaatannya. Cakra Kimia Indonesia, 6(2), 79-97.

Rimadani, E., Parno, \& Diantoro, M. (2017). Identifikasi Kemampuan penalaran ilmiah siswa sma pada materi suhu dan kalor. Jurnal Pendidikan: Teori, Penelitian Dan Pengembangan, 2(6), 833-839.

Sari, L. I., Zulhelmi, \& Azizahwati. (2019). An analysis scientific reasoning ability of Class $X$ student SMA Negeri at Tampan District Pekanbaru in Subject Work and Energy. Jom Fkip, 6(2), 1-14.

Senathirajah, T., Rasalingam, S., \& Ganeshalingam, S. (2017). Extraction of the cyanidin3-sophoroside from hibiscus rosa-sinensis: An efficient natural indicator over a wide range of acid-base titrations. Scholars Research Library, 7(3), 1-7.

Setiawati, D. A., Setiati, N., \& Pribadi, T. A. (2019). The development of e-atlas learning media based on mobile learning on cells structure concept. Journal of Biology Education, 8(1), 15-25. https://doi.org/10.2991/icssis-18.2019.32

Shanmukha, I., Patel, H., Patel, J., \& Riyazunnisa. (2011). Quantification of total phenol and flavonoid content of delonix regia flowers. International Journal of ChemTech Research, 3(1), 280-283.

Shishir, M. N., Laxman, J. R., Vinayaj, P. N., Jacky, D. R., \& Bhimrao, G. S. (2014). Use of argyreia cuneata flower extract as a natural indicator in acid base titration. Journal of Current Pharma Research, 4(2), 1124-1127. https:// doi.org/10.33786/jcpr.2014.v04i02.002

Song, H., Yi, H., Lee, M., Han, C. T., Lee, J., Kim, H. R., Park, J. I., Nou, I. S., Kim, S. J., \& Hur, Y. (2018). Purple Brassica oleracea var. capitata F. rubra is due to the loss of BoMYBL2-1 expression. BMC Plant Biology, 18(1), 1-16. 
https:// doi.org/10.1186/s12870-018-1290-9

Suzihaque, M. U. ., Farzana, N., \& Mohd, B. (2019). Development of Intelligent food packaging from red cabbage anthocyanin pigment. International Journal of Recent Technology and Engineering, 8(4), 6798-6802. https://doi.org/10.35940/ijrte.d5225.118419

Tejaputri, N. A., Arsianti, A., Qorina, F., \& Fithrotunnisa, Q. (2019). Phytochemical analysis and antioxidant properties by DPPH radical scavenger activity of ruellia brittoniana flower. International Journal of Applied Pharmaceutics, 11(6), 24-28. https://doi.org/10.22159/ijap.2019.v11s6.33531

Trojak, M., \& Skowron, E. (2017). Role of anthocyanins in high-light stress response. World Scientific News, 81(2), 150-168.

Vadivel, E., \& Chipkar, S. D. (2016). Eco-friendly natural acid-base indicator properties of four flowering plants from western ghats. International Journal of Pharmacy and Pharmaceutical Sciences, 8(6), 250-252.

Wu, H., Effects, H. C., Wu, H., Weng, H., \& She, H. (2016). Effects of scaffolds and scientific reasoning ability on web-based scientific inquiry. International Journal of Contemporary Educational Research, 3(1), 12-24.

Wulansari, L. D. (2015). Pengembangan atlas keanekaragaman tumbuhan: Euphorbiales, myrtales, dan solanales sebagai sarana identifikasi. Berkala Ilmiah Pendidikan Biologi (BioEdu), 3(1), 21-30.

Wuriyudani, H. A., Wiyanto, W., \& Darsono, T. (2018). Problem Solving heuristic to develop scientific reasoning. Physics Communication, 3(1), 1-9. https://doi.org/10.15294/physcomm.v3i1.15022

\footnotetext{
${ }^{*}$ Raddina Aprilia Putri (Corresponding Author)

Graduate Programs, Science Education,

State University of Surabaya,

Jl. Lidah Wetan, Surabaya, East Java, Indonesia

Email: raddina.19016@mhs.unesa.ac.id

Prof. Dr. Endang Susantini, M.Pd.

Graduate Programs, Science Education,

State University Of Surabaya,

Jl. Lidah Wetan, Surabaya, East Java, Indonesia

Email: endangsusantini@unesa.ac.id

Prof. Dr.Titik Taufikurohmah, M.Si.

Graduate Programs, Science Education,

State University Of Surabaya,

Jl. Lidah Wetan, Surabaya, East Java, Indonesia

Email: titiktaufikurohmah@unesa.ac.id
} 